DOI: 10.20472/BMC.2021.012.006

PAVEL KRUPÍK

Czech Technical University in Prague, Faculty of Civil Engineering, Czech Republic

\title{
STRATEGIC PLANNING OF INVESTMENTS IN THE DEVELOPMENT OF MOTORWAYS AND FIRST CLASS ROADS FROM THE PERSPECTIVE OF ECONOMIC EVALUATION
}

\begin{abstract}
:
The subject of this article is to describe how strategic planning of investments in the development of motorways and class I roads is currently carried out and what role economic evaluation plays in this process. The author uses data from 2014 to 2020 from the investor, the Road and Motorway Directorate of the Czech Republic. The author of this article would like to point out that from the point of view of strategic planning, the preparation of an economic evaluation is not a single and self-sufficient indicator. Certainly, it will give a hint whether or not to implement a project at all, but it does not help to determine which of the two projects to choose if the investor has limited finances.
\end{abstract}

\section{Keywords:}

Strategic planning, economic evaluation, motorways, first class roads

JEL Classification: R42 


\section{Introduction}

When planning the construction of new motorways and first-class roads or increasing the capacity of existing ones, an economic evaluation of the project is carried out as a priority. If the project shows values of economic indicators above the level of economic efficiency, it is usually approved and its preparation and further implementation proceeds. However, the current system does not currently take into account the economic situation of the country at the time of its expected implementation. Virtually all projects that are ready in terms of permitting processes and property settlement are being implemented. Up to now, there have been sufficient funds for the preparation of transport infrastructure projects and their subsequent implementation, but this may not be the case in the future due to the reduction/suspension of EU subsidies. This situation is already starting to manifest itself.

\section{$2 \quad$ Planning and preparation process for motorways and first class roads}

The whole process of strategic planning of investments in the development of the motorway and first class road network can be simplified in Figure 1 below, which is based on [1].

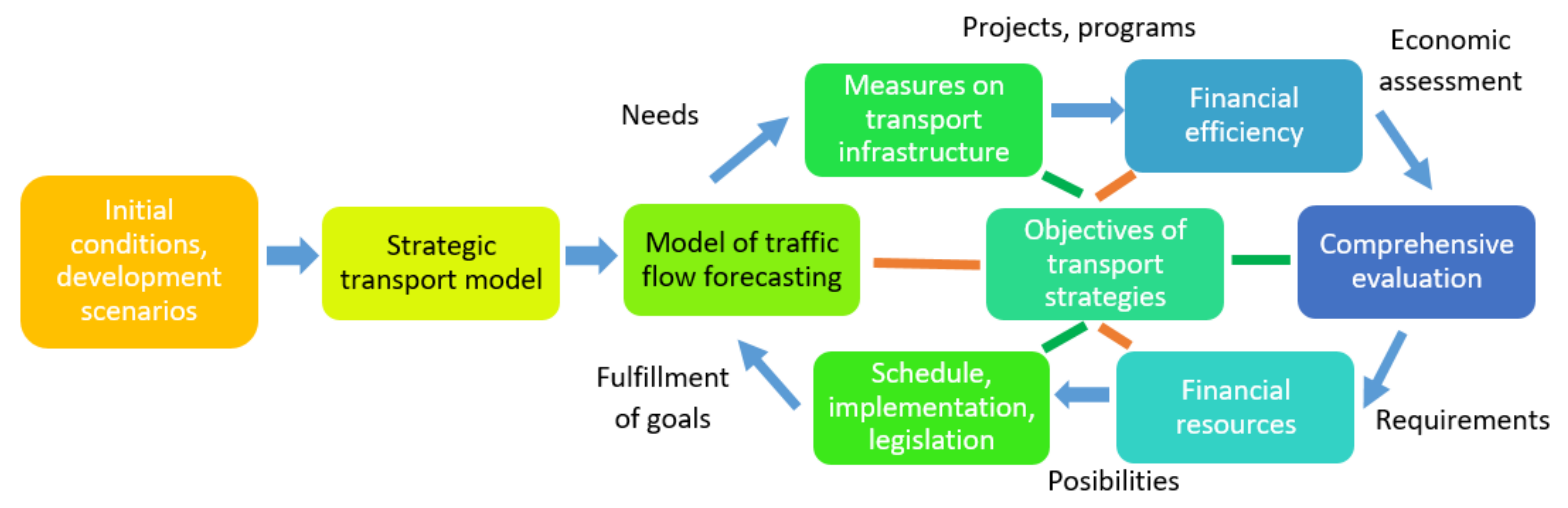

Figure 1: Process of strategic planning

Source: [1], modified by the author

The obligation to prepare an evaluation of the economic efficiency of transport infrastructure projects in the Czech Republic financed without the participation of the state budget results from the Directive of the Ministry of Transport V-2/2012 as currently in force. It obliges investors (in the case of motorways and first class roads) to prepare a project plan or its update [2].

The project plan is understood as a documentation that defines the requirements for the preparation and implementation of the project in time, substance and function in the details necessary for the assessment and issuance of the opinion of the Ministry of Transport. Its preparation and approval is a condition for the commencement of financing of the subsequent preparation and implementation of an investment or non-investment project to be financed from the budget of the State Fund for Transport Infrastructure (SFDI) as a nominal project [2].

A key part of the project design is the evaluation of the economic efficiency of the project. The evaluation of the economic efficiency of the project is prepared in accordance with the current version of the Departmental Guideline for the evaluation of economic effectiveness of transport construction projects [2, 3].

The evaluation of the economic efficiency of a project prepared in accordance with the Implementing Guidelines shall result in at least the following key economic indicators: (economic) internal rate of return (IRR), (economic) net present value (NPV) and (economic) 
break-even cost (BCR), calculated at a binding uniform (economic) discount rate, unless an alternative expert method provides otherwise [2].

The Implementing Guidelines [4] list several possibilities when the assessment of economic efficiency is not carried out according to the applicable departmental methodology:

"The evaluation of the effectiveness of projects is carried out by justifying data and indicators that express specific benefits for users, population, economy (e.g. reduction in the number or severity of traffic accidents, reduction in the number of inhabitants affected by excessive noise, etc.), taking into account the purpose of the construction, in the following cases:

a) elimination of the consequences of accidents, landslides, flood damage, or the consequences of other catastrophic events by investing in the emergency parts of the building to improve the construction parameters, the quality of construction or the technical design,

b) separate construction measures to remove accident and operationally dangerous sites and sections,

c) additional or separate construction measures resulting from Act No. 258/2000 Coll. (On the Protection of Public Health) and Act No. 254/2001 Coll. (Water Act), as amended, and Act No. 100/2001 Coll. on Environmental Impact Assessment and on Amendments to Certain Related Acts (Environmental Impact Assessment Act), as amended,

d) land acquisition, land reclamation, geodetic measurements and geotechnical surveys, unless they are part of the construction,

e) equipment for the maintenance of transport structures and roads (e.g. buildings, areas, landfills, mechanisation),

f) traffic signs, safety and information equipment, telematics (financially or materially defined),

g) for buildings ensuring the performance of the property administration of the Road Infrastructure Directorate of the Czech Republic on roads - maintenance, repair and reconstruction of existing roads, including bridges,

h) measures to eliminate defects in passability and navigability according to Act No. 13/1997 Coll, on roads, as amended,

i) road and motorway maintenance facilities (buildings, areas, landfills, SSSDs), accessory equipment and road service facilities (e.g. separately built rest areas)." [3]

The existing methodologies used in the Czech Republic are based on Cost-Benefit Analysis (CBA), which is based on the analysis of the differential cash flows of costs and benefits at the time of project evaluation. The method compares the benefits that the investment brings with the negative investment effects. All impacts of the investment (whether positive or negative) are converted into cash flows and included in the calculation of key indicators.

\section{Methodology}

The research used data on the processing of project plans or project updates from the Directorate of Roads and Motorways for the period from 2014 up to and including June 2020. A total of 362 project plans and project updates were processed during this period.

\section{Results}

An economic evaluation was carried out for a total of 236 project plans and project updates. For the others, no economic evaluation was carried out due to the possibility of using an exception. A full 35\% (as shown in Figure 2) of the project plans and their updates did not have an economic evaluation. 


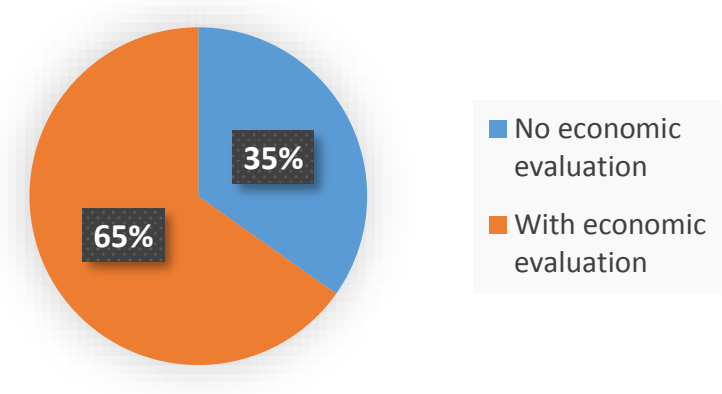

Figure 2: Percentage of economic evaluations completed

Source: data of the Directorate of Roads and Motorways, processing by the author

The BCR (cost-effectiveness) criterion was selected as the evaluation criterion from the economic evaluations carried out. Only one project achieved a value below one, i.e. it is not profitable. After adjustments were made (economic evaluation as part of the project plan update), this transport infrastructure project also came out as cost-effective (i.e. BCR higher than 1).

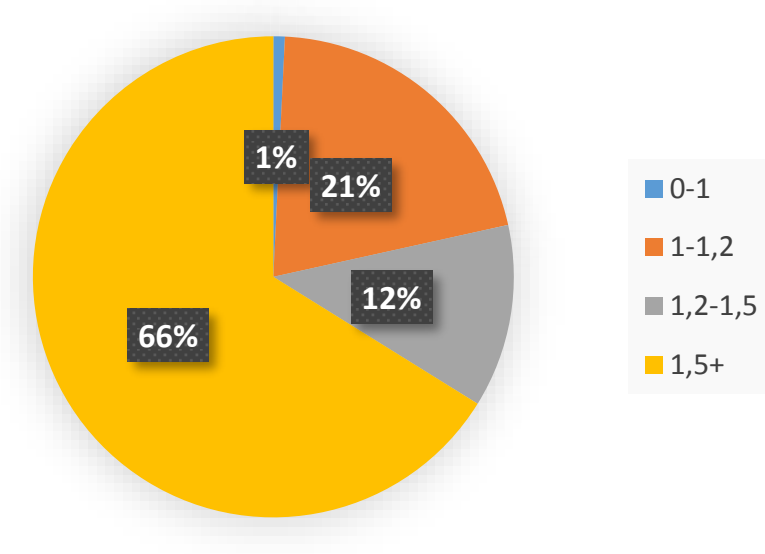

Figure 3: Proportion of the range of BCR values achieved for project plans

Source: data of the Directorate of Roads and Motorways, processing by the author

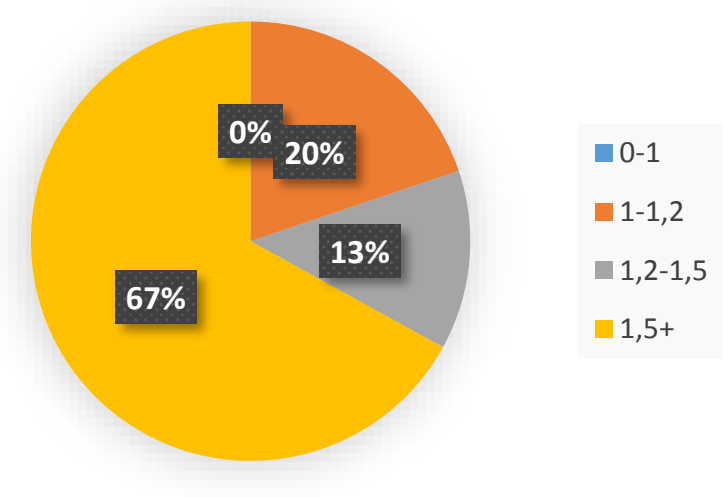

Figure 4: Proportion of the range of BCR values achieved for updated project plans

Source: data of the Directorate of Roads and Motorways, processing by the author

Based on the observed data, it can be concluded that the vast majority of projects are clearly effective according to the economic evaluation. Only about $20 \%$ of the projects came out in 
the author's chosen grey zone (i.e. BCR up to 1.2), where it is possible to count on some inaccuracy based on input parameters projected into the distant future (e.g. traffic load).

The data obtained shows that from the point of view of strategic planning, the preparation of an economic evaluation is not the only and self-sufficient indicator. It will certainly give a clue as to whether a project should be implemented at all, but it will not help determine which of the two projects to choose if the investor has limited financial resources. It is therefore suggested to use alternative ways of evaluating transport infrastructure projects.

One of the options for prioritising a transport project is the use of a multi-criteria analysis, which evaluates individual solutions according to precisely defined criteria and their weighting. A project receives points if it meets a given criterion. These are then multiplied by the weight of the criterion [6]. The choice of a classification algorithm is an important problem in many domains. Since it usually involves more than one criterion, the task of algorithm selection can be modeled as a multi-criteria decision problem [7].

Another option is to use value engineering methodologies. Specifically, Value Engineering (VE) [5] provide an analysis of project objectives and attributes, which then focuses the development of alternatives in a value study. This method can be used to emphasize efficient use of resources, improve project performance, and achieve cost savings throughout the life cycle of transportation structures. Measuring project performance quantifies the quality of project objectives and the timeframe in which they are met, which in turn allow the value of the project to be determined. The use of VE in the public sector has resulted in significant improvements in project performance and cost savings. Improving the relationship between project performance and life cycle costs has been a major benefit for public projects.

The inadequacy of the CBA is confirmed by the findings of other authors. For example, [8] states that the CBA method only helps the owner to decide whether the investment is acceptable and efficient and that the results are not sufficiently predictive. For example, a project may be built that is highly valuable to the public but may generate significant negative cash flows. Further economic and management studies (case studies or feasibility studies) should be carried out to assess this further.

\section{Conclusion}

The problem is therefore probably not the evaluation itself and its optimisation, but the lack of a clear methodology, rules, a specific timetable and above all the prioritisation of individual projects (similar to the National Investment Plan). In the long term, it is realistic that there will no longer be enough funds to implement all the projects prepared. The problem is therefore rather the absence of a long-term plan for the development of transport infrastructure and the lack of clarity of the criteria according to which the projects to be implemented are determined.

\section{References}

[1] CZECH REPUBLIC. Ministry of Transport of the Czech Republic. Dopravní sektorová strategie - aktualizace 2017, Střednědobý plan rozvoje dopravní infrastruktury s dlouhodobým výhledem Available online at: http://www.dopravnistrategie.cz/images/projekt/ke-stazeni/Aktualizace2017/III_DSSAktualizace2017_Materil_PoZZ.pdf

[2] CZECH REPUBLIC. Ministry of Transport of the Czech Republic. Guideline no. V-2/2012 Change No. 5, Směrnice upravující postupy $v$ průběhu přípravy investičních a neinvestičních akcí dopravní infrastruktury, financovaných bez účasti státního rozpočtu. Available online at: https://www.mdcr.cz/Dokumenty/Ministerstvo/Vnitrnipredpisy/Smernice-V-2-2012 
[3] CZECH REPUBLIC. Ministry of Transport of the Czech Republic. Departmental Guideline for the evaluation of economic effectiveness of transport construction projects Available online at: https:/www.sfdi.cz/soubory/obrazkyclanky/metodiky/2017_03_departmental-methodology-full.pdf

[4] CZECH REPUBLIC. Ministry of Transport of the Czech Republic. Prováděcí pokyny pro hodnocení efektivnosti projektů dopravní infrastruktury Available online at: https://www.sfdi.cz/soubory/obrazkyclanky/metodiky/2017_provadeci_pokyny_efektivnost.pdf

[5] HERALOVA, Renata Schneiderova. Possibility of Using Value Engineering in Highway Projects. Procedia Engineering [online]. 2016, 164, 362-367. ISSN 18777058. Available online at: doi:10.1016/j.proeng.2016.11.631

[6] PILAŘOVÁ, Irena. Leadership \& management development: role, úlohy a kompetence managerů a lídrů. Praha: Grada, 2016. ISBN 978-80-247-5721-6.

[7] KOU, GANG, YANQUN LU, YI PENG a YONG SHI. EVALUATION OF CLASSIFICATION ALGORITHMS USING MCDM AND RANK CORRELATION. International Journal of Information Technology \& Decision Making [online]. 2012, 11(01), 197-225. ISSN 0219-6220. Available online at: doi: 10.1142/S0219622012500095

[8] HERALOVA, Renata Schneiderova, Eduard HROMADA a Hal JOHNSTON. Cost Structure of the Highway Projects in the Czech Republic. Procedia Engineering. 2014, 85, 222-230. ISSN 18777058. Available online at: doi:10.1016/j.proeng.2014.10.547

\section{Acknowledgments}

This work was supported by the Grant Agency of the Czech Technical University in Prague, grant No. SGS20/100/OHK1/2T/11. 